University of Nebraska - Lincoln

DigitalCommons@University of Nebraska - Lincoln

Faculty Publications from the Harold W. Manter Laboratory of Parasitology

1996

Re-Evaluation of Mazamastrongylus dagestanica (Trichostrongylidae) with Descriptions of the Synlophe, Genital Cone, and Other Structural Characters

Eric P. Hoberg

United States Department of Agriculture, Agricultural Research Service, geocolonizer@gmail.com

A. V. Khrustalev

K. I. Skrjabin Institute of Helminthology

Follow this and additional works at: https://digitalcommons.unl.edu/parasitologyfacpubs

Part of the Parasitology Commons

Hoberg, Eric P. and Khrustalev, A. V., "Re-Evaluation of Mazamastrongylus dagestanica (Trichostrongylidae) with Descriptions of the Synlophe, Genital Cone, and Other Structural Characters" (1996). Faculty Publications from the Harold W. Manter Laboratory of Parasitology. 730. https://digitalcommons.unl.edu/parasitologyfacpubs/730

This Article is brought to you for free and open access by the Parasitology, Harold W. Manter Laboratory of at DigitalCommons@University of Nebraska - Lincoln. It has been accepted for inclusion in Faculty Publications from the Harold W. Manter Laboratory of Parasitology by an authorized administrator of DigitalCommons@University of Nebraska - Lincoln. 


\title{
RE-EVALUATION OF MAZAMASTRONGYLUS DAGESTANICA (TRICHOSTRONGYLIDAE) WITH DESCRIPTIONS OF THE SYNLOPHE, GENITAL CONE, AND OTHER STRUCTURAL CHARACTERS
}

\author{
E. P. Hoberg and A. V. Khrustalev* \\ United States Department of Agriculture, Agricultural Research Service, Biosystematic Parasitology Laboratory, \\ BARC East No. 1180, 10300 Baltimore Avenue, Beltsville, Maryland, 20705-2350
}

\begin{abstract}
The synlophe of specimens of Mazamastrongylus dagestanica was characterized laterally and ventrally by a strongly tapering system of ridges in the cervical zone. This pattern, including the prominent system of "hood" ridges adjacent to the excretory pore and the absence of continuous subdorsal and subventral ridges is considered typical for the genus Mazamastrongylus. The synlophe of males and females was largely identical, with $37-41$ ridges at the midbody. The lateral synlophe, where 2 pairs of ridges converge and terminate on the lateralmost ridge anterior to the cervical papillae appears unique for $M$. dagestanica and indicates that species-specific patterns may be recognized for Mazamastrongylus spp. Among male specimens, a bilobed ventral membrane, distinct from the simple and unpaired membrane, which envelops the " 0 " papillae, extends posterolaterally from the genital cone. It had not been described in detail previously and was also found in $M$. odocoilei and $M$. pursglovei. Characters of the bursa, genital cone, and spicules are consistent with placement of $M$. dagestanica in Mazamastrongylus; referral of this species to Spiculopteragia cannot be supported.
\end{abstract}

Specimens of the ostertagiine nematode Mazamastrongylus dagestanica (Altaev, 1953) were originally described as Skrjabinagia dagestanica Altaev, 1953 in Ovis aries Linnaeus from the Dagestan Republic of the Former Soviet Union. Although controversial, the present position of this species in Mazamastrongylus Cameron, 1935 was proposed by Jansen (1986). Spiculopteragia alcis Shult's, Kadenatsii, Evranova, and Schaldubin, 1954 from cervids and Spiculopteragia popovi Evranova, 1954 were considered to be synonyms according to Andreeva (1956) and these were later synonymized with $M$. dagestanica by Dróżdż (1965) and Jansen $(1958,1986)$. The date for $S$. alcis is often given as 1952 (the name appears in Skrjabin et al. [1952]), however the original description apparently was published later (Skrjabin et al., 1954). Thus, by priority, S. alcis must be reduced as a synonym of $M$. dagestanica (see Dróżdż, 1965), in contrast to the listing by Durette-Desset (1989). Although reported from sheep, the species is considered to be a typical parasite of cervids, including Capreolus capreolus (Linnaeus), Alces alces (Linnaeus), and Cervus elaphus Linnaeus in the Palearctic (Govorka et al., 1988; Dróżdż, 1965, 1967, 1995).

The history of $M$. dagestanica is complex and has been reviewed in part by Dróżdż (1965) and Hinaidy and Prosl (1981). Following the original description, this species was retained in Skrjabinagia (Kassimov, 1942) by Skrjabin et al. (1954). Sarwar (1957) established Altaevia Sarwar, 1957, referred S. dagestanica to the genus and distinguished it from Spiculopteragia (Orloff, 1933); the subfamily Spiculopteragiinae was created for Altaevia, Mazamastrongylus, and Spiculopteragia. Jansen (1958) transferred $S$. dagestanica to Spiculopteroides Jansen 1958 and S. alcis to Mazamastrongylus.

Dróżdż (1965) outlined the taxonomy for $S$. dagestanica, referred it to Spiculopteragia, and recognized Spiculopteroides dagestanica, Altaevia dagestanica, S. alcis, S. popovi Evranova, 1954, and Mazamastrongylus alcis as synonyms. The genus

Received 23 January 1996; revised 25 April 1996; accepted 25 April 1996.

* K. I. Skrjabin Institute of Helminthology, Central Helminthological Museum, Bol'shaya Cheryomushinskaya, 28, 117259 Moscow, M-259, Russia.
Altaevia was reduced as a synonym of Spiculopteragia, but $M a$ zamastrongylus was regarded as valid. The tribe Spiculopteragiini (Sarwar, 1957) was established in the subfamily Ostertagiinae to contain Spiculopteragia, Mazamastrongylus, Apteragia Jansen, 1958, Rinadia Grigorian, 1951, and Sarwaria Dróżdż, 1965.

Hinaidy and Prosl (1981) recognized the validity of Spiculopteroides and referred $S$. dagestanica to this genus. They also commented on the possible synonymy of this genus and $\mathrm{Ma}$ zamastrongylus. Durette-Desset $(1982,1983)$ listed Mazamastrongylus, Spiculopteroides, Altaevia, and three other genera as synonyms of Spiculopteragia.

Jansen $(1986,1989)$ synonymized Spiculopteroides with $\mathrm{Ma}$ zamastrongylus and resurrected the latter genus. Among 8 species of ostertagiines, $M$. dagestanica (with $S$. alcis as a synonym) was placed in Mazamastrongylus. The genus was defined by the configuration of the ventral and lateral rays of the copulatory bursa and the structure of the accessory bursal membrane (Jansen, 1986).

Durette-Desset (1989), consistent with her previous decisions, presented Mazamastrongylus as a synonym of Spiculopteragia. The species $S$. dagestanica, $S$. popovi, and $S$. alcis were referred to Spiculopteragia and listed independently.

Dróżdż (1995) discussed polymorphism among males in several genera of ostertagiines and found this characteristic to be absent in species referred to Mazamastrongylus. Mazamastrongylus dagestanica and 4 additional species were referred to the genus.

Hoberg (1996) reevaluated the status of Mazamastrongylus and in agreement with Jansen $(1986,1989)$ and Dróżdż (1995) recognized the genus as independent from Spiculopteragia and other genera of ostertagiines. In contrast to Jansen (1986) and Dróżdż (1995), 7 species, including $M$. dagestanica, were placed in the genus (only Sarwaria bubalis (Sarwar, 1956) was excluded). In addition to attributes outlined by Jansen (1986), the spoon-shaped dorsal process of the spicules was considered as a defining character for Mazamastrongylus.

In the current study, we confirm the placement of $M$. dagestanica in the genus Mazamastrongylus, with reference to $\mathbf{M a}$ zamastrongylus trinitatis Cameron, 1935 (type) and other spe- 
cies. Conclusions are based on the first detailed study of the structure and configuration of the cervical synlophe and esophagus. Aspects of these characters and the bursa, genital cone, and spicules are considered within a comparative morphological context. The synlophe is compared among those species, including Mazamastrongylus pursglovei (Davidson and Prestwood, 1979), Mazamastrongylus odocoilei (Dikmans, 1931), Mazamastrongylus peruvianus (Guerrero and Chávez, 1967), and $M$. trinitatis, where the pattern of longitudinal cuticular ridges has been assessed (Lichtenfels et al., 1993; Hoberg, 1996). This study represents a contribution to ongoing efforts that attempt to stabilize the generic-and species-level systematics within the Ostertagiinae (e.g., Durette-Desset, 1982, 1983, 1989; Gibbons and Khalil, 1982; Jansen, 1989; Lichtenfels and Hoberg, 1993; Hoberg and Lichtenfels, 1994; Dróżdż, 1995).

\section{MATERIALS AND METHODS}

Specimens were studied as temporary wholemounts cleared in phenol-alcohol ( 80 parts melted phenol crystals and 20 parts absolute ethanol) or in glycerine and examined with differential interference contrast light microscopy. Transverse sections of 2 males and 2 females were prepared freehand with a cataract knife and embedded in glycerine jelly. Sections were used to study the structure of the synlophe in the cervical zone (including the region of the esophageal-intestinal junction), anterior quarter, midbody, and posterior region. Figures of sections were orientated with dorsal surface toward the top of the plate and shown as if viewed from the anterior. Throughout the manuscript, measurements are presented in micrometers unless specified otherwise and presented as a range with mean $\pm 1 \mathrm{SD}$ in parentheses; measurements were based on 20 specimens of each sex.

The current study focused on the configuration of the synlophe, esophageal valve, and genital cone (following Lichtenfels and Pilitt, 1991; Hoberg et al., 1993a). Other meristic and structural characters are also evaluated (measurements of the ovejectors follow Lichtenfels and Pilitt [1991]). Genital papillae and bursal rays are numbered according to the methodology developed by Chabaud et al. (1970), and the terminology for the genital cone is consistent with Stringfellow $(1971,1972)$ and Gibbons and Khalil (1983). The orientation of the synlophe follows concepts presented by Durette-Desset $(1983,1985)$.

Specimens examined: Mazamastrongylus dagestanica (Altaev, 1953) (labeled as Spiculopteragia alcis Shul'ts, Kadenazii, Evranova, and Schaldubin, 1954) in A. alces (Linnaeus) from the Prioksko Reserve, adjacent to the Oka River approximately $160 \mathrm{~km}$ south of Moscow, Russia; 40 males and 40 females were examined, including 20 adult nematodes of each sex from the K. I. Skrjabin Institute of Helminthology nos. 19140 and 24553.

Additional specimens for comparative purposes included: (1) U.S. National Parasite Collection (USNPC) no. 73914, M. pursglovei (Davidson and Prestwood, 1979) (paratype specimens of Apteragia pursglovei Davidson and Prestwood, 1979) in Odocoileus virginianus (Zimmermann) from South Carolina and no. 70318, M. pursglovei in $O$. virginianus from Louisiana; (2) USNPC no. 29427, M. odocoilei (Dikmans, 1931) (type specimens of Ostertagia odocoilei Dikmans, 1931) in O. virginianus from Pennsylvania and USNPC no. 70309, M. odocoilei in $O$. virginianus from Georgia; (3) USNPC no. 59236, M. peruvianus
(Guerrero and Chávez, 1967) in alpaca (Lama pacos Linnaeus) from Puno, Peru; and (4) Institute of Parasitology, McGill University, Ste-Anne-de-Bellevue, Quebec, Canada, no. V000751, M. trinitatis Cameron, 1935 in Mazama americana (Erxleben) (originally listed as Mazama simplicicornis by Cameron [1935]) from Trinidad.

\section{RESULTS}

A re-evaluation of $M$. dagestanica included characters not considered in detail in the original description and subsequent redescriptions. Among these are attributes of the synlophe, esophagus, genital cone, spicules, and vulval region (Figs. 127). Meristic data are presented in Table $I$, which augment the original description, previous redescriptions, and observations presented below.

\section{Synlophe}

The synlophe is composed of a symmetrical system of discontinuous tapering cuticular ridges extending from the base of the cephalic expansion to near the caudal extremity in males and females (Figs. 1-4). Ridges are perpendicular to the body wall and lack a defined gradient (Figs. 5-10). In the cervical zone (anterior to the base of the esophagus), 18 ridges attain the base of the cephalic expansion. There are 29-38 ridges at the level of the minuscule thornlike cervical papillae in males. Variation in numbers is attributable to short discontinuous ridges and differences in the level of origin and termination for individual ridges in the cervical zone (Figs. 1-4). At the limit of the esophageal-intestinal (EI) junction, there are 34-36 ridges in males and 34-35 in females (Figs. 5, 8). The synlophe is of even height and the interval between ridges is less laterally than in either the dorsal or ventral fields.

Overall, the synlophe is defined by a tapering pattern in both the ventrodorsal and lateral fields. Laterally, a strongly tapering pattern is evident with 2 pairs of ridges consistently terminating anterior to the cervical papillae; posterior to the cervical papillae, variable pairs of ridges terminate adjacent to the lateralmost ridge in the cervical zone (Figs. 2, 4). Ventrally the ridges form a hood adjacent to the protruding and prominent excretory pore (Figs. 1, 3). Pairs of ridges extend posteriad across the ventral and dorsal fields to terminate on the lateralmost ridges; continuous subventral and subdorsal ridges are lacking; the synlophe is defined by 4 continuous ridges, left and right lateral and dorsal and ventral (Figs. 1-4). Variation in the ventral synlophe is evident, with 2 recognizable patterns in the cervical region posterior to the excretory pore. In $85 \%(n=20$ males and 20 females, respectively) of specimens the ventral ridge is discontinuous in the cervical zone, with a substantial interruption posterior to the excretory pore (Fig. 1). In $15 \%$ of specimens, a definable ventral ridge is interrupted only at the excretory pore (Fig. 3).

The tapering pattern continues for approximately $29-54 \%$ of the body from the anterior in males and $31-49 \%$ in females. In the posterior half, ridges are parallel, with 3-4 closely spaced ridges in each lateral field; in the subventral and subdorsal fields, irregular termination and origin of ridges occurs in the posterior half of the body. The synlophe extends from the cephalic extremity to near the level of the prebursal papillae in males and to the level posterior of the anus in females. 

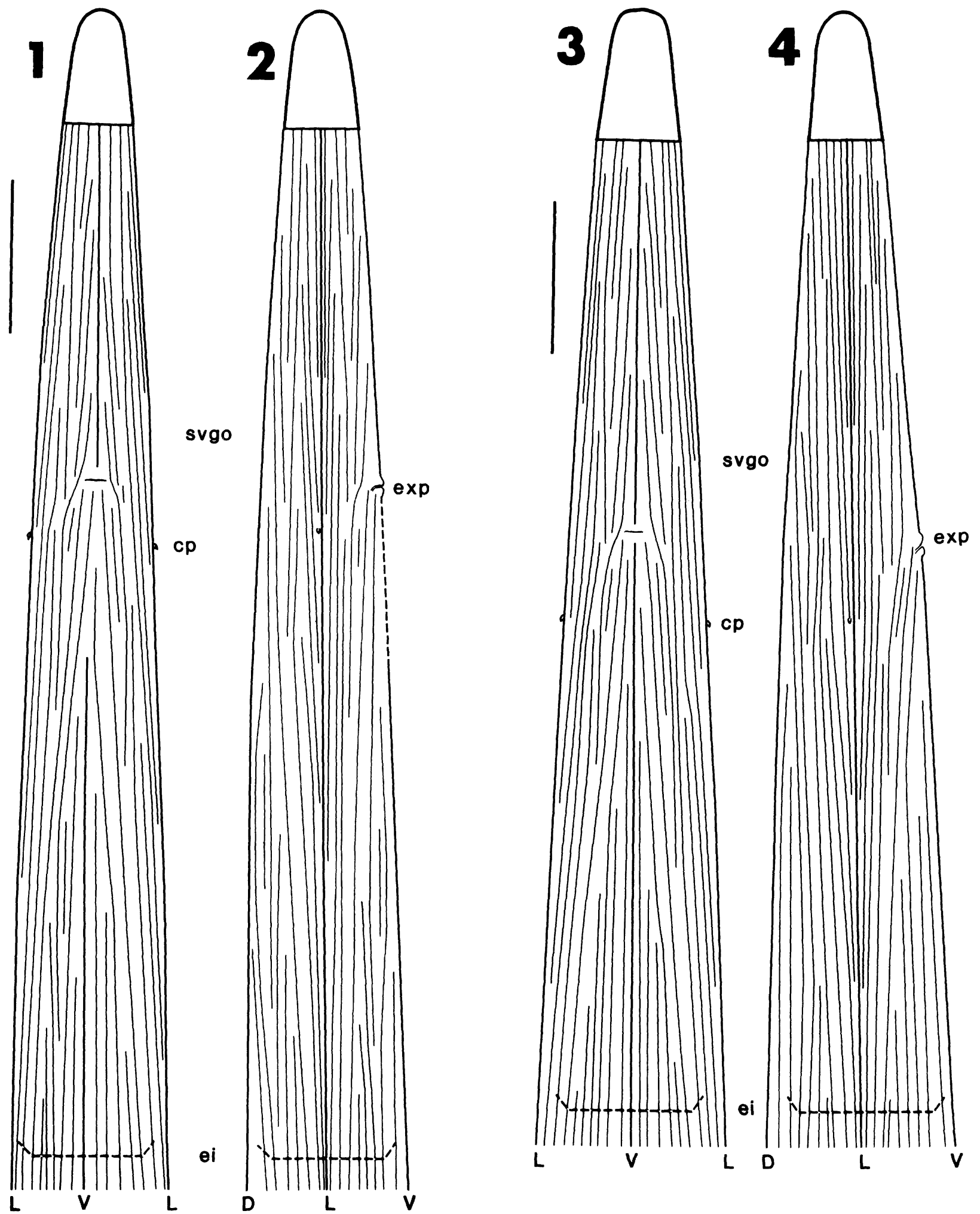

FIGUREs 1-4. Synlophe in the cervical region of Mazamastrongylus dagestanica (Altaev, 1953) anterior to the esophageal-intestinal junction (ei) showing pattern and positions of the subventral gland orifices (svgo), excretory pore (exp), and cervical papillae (cp) in male and female specimens (scale bars $=100 \mu \mathrm{m}$ ). 1. Ventral synlophe showing tapering pattern with ridges extending across to the lateral fields (L), typical hood ridges at level of broad liplike excretory pore, and ventral ridge interrupted posterior to the excretory pore (V); this ventral pattern is observed in $85 \%$ of male and female specimens. 2. Lateral synlophe showing strongly tapering pattern extending posterior from cervical papillae; note 2 pairs of ridges terminating anterior to the cervical papillae; dotted line indicates interrupted ventral ridge. 3. Ventral synlophe showing pattern typical of $15 \%$ of specimens in which the ventral ridge is discontinuous only at the excretory pore. 4 . Lateral synlophe in specimens with alternate ventral pattern in cervical zone. 

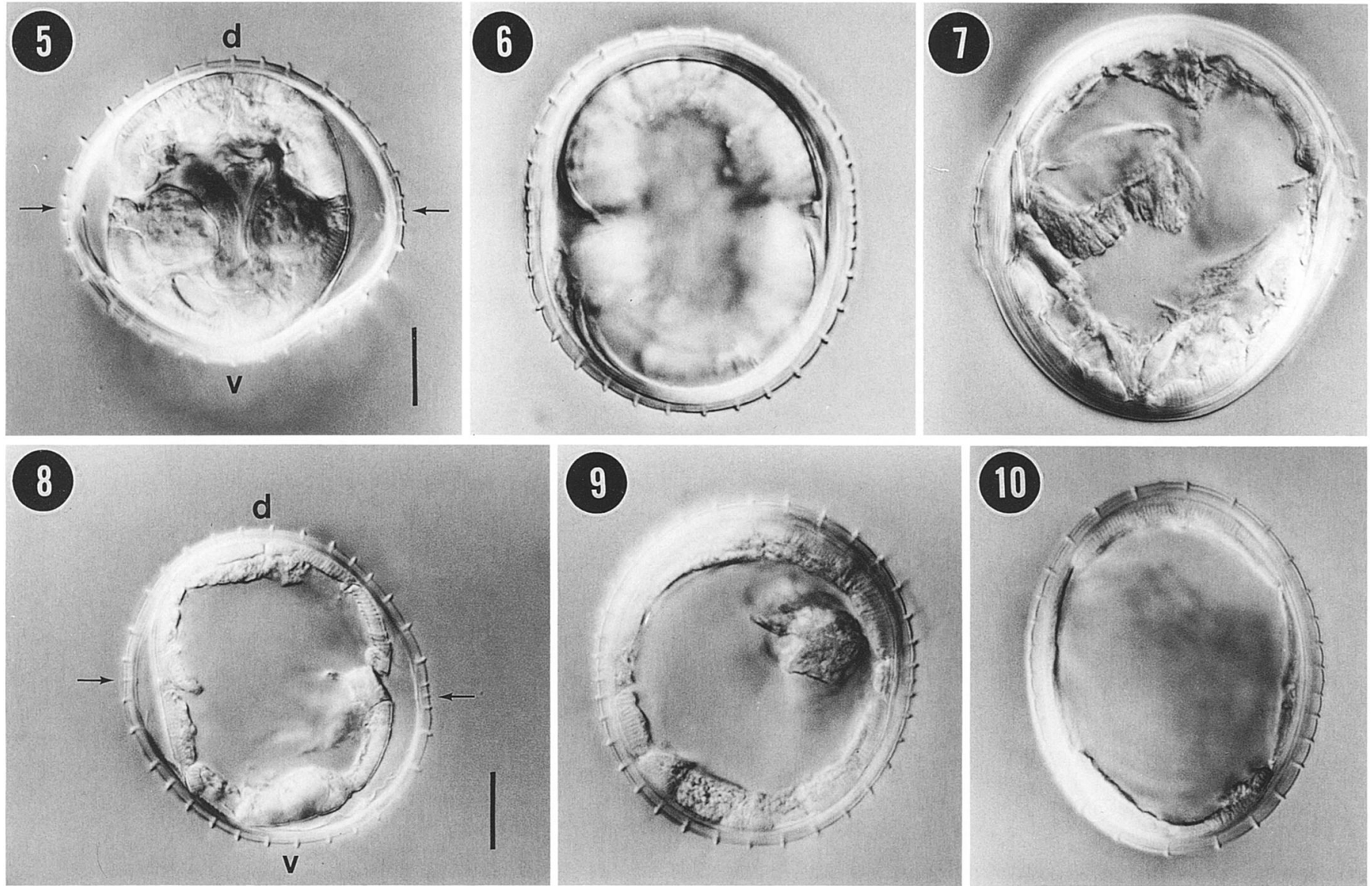

FIGURES 5-10. Mazamastrongylus dagestanica (Altaev, 1953) showing structure of the synlophe in transverse sections of males (Figs. 5-7) and females (Figs. 8-10) (scale bars $=20 \mu \mathrm{m}$ for all figures). 5. Level of esophageal-intestinal junction (EI) in male, showing 36 ridges; note minuscule lateralmost ridges (arrows) and dorsal (d) and ventral (v) ridges; ridges are perpendicular. 6. Midbody showing 37 ridges. 7. Level anterior to prebursal papillae showing retention of ridges only in lateral fields and prominent gaps in the dorsal and ventral fields. 8. Level of EI in female showing 34 ridges. 9. Midbody showing 37 ridges. 10. Posterior to the vulva, showing 32 ridges.

Posterior to the cervical zone, there are $38-42$ and $41-44$ ridges at the end of the first quarter in males and females; at the midbody, there are 37 and $37-41$, respectively (Figs. 6, 9). A poorly defined gradient in size is evident, with ridges in the lateral fields being slightly smaller than those disposed ventrally and dorsally; the interval between ridges is also greater in the ventral and dorsal fields. In males by the third quarter there are 35-36 ridges. In the posterior, ridges terminate first ventrally at $338-637 \mu \mathrm{m}$ anterior to the prebursal papillae, $92-95 \%$ of body length from the anterior, and then dorsally at $234-463$ $\mu \mathrm{m}, 94-97 \%$ of body length from the anterior, forming arcuate gaps. Anterior to the spicules and prebursal papillae, the synlophe is lacking dorsally and ventrally and ridges decrease to $15-19$ in the lateral fields, with these extending to the level of the prebursal papillae (Fig. 7).

In females, there are 35-36 ridges in the third quarter, decreasing to 32-33 posterior to the vulva (Fig. 10), with the synlophe extending to the tail.

\section{Esophagus}

The esophagus is claviform, with the widest region being near the level of the esophageal-intestinal valve (EI). The orifices of the subventral esophageal glands are located anterior to both the cervical papillae and the excretory pore (Table I). The EI valve is relatively long in males and females (81-99 $\mu \mathrm{m}$ ) (Table I; Fig. 16). A minuscule, triangular, dorsal esophageal tooth is present.

\section{Bursal pattern and genital cone}

The bursal pattern is 2-2-1 (see Durette-Desset, 1983), with rays 2 and 3 parallel throughout, and rays 4 and 5 near equal in length and divergent distally (see also Altaev, 1953; Andreeva, 1958; Dróżdż, 1965). The body of the genital cone is bluntly rounded (Figs. 11, 19, 21); a proconus is absent. Ventrally, a pair of lateral processes extend from the cloacal plate (Figs. 11, 20). The "0" papillae are paired, relatively long, and contained within a membrane (Figs. 11, 19, 20). A prominent bilobed membrane extending from the posterolateral margins of the ventral cloacal plate resides dorsal to the " 0 " papillae at the level of the ventral margin of the cloacal orifice (Figs. 11, 19, 20); proximally there are a pair of granular lobes extending into the base of the membranes (Fig. 11). The bilobed membrane is distinct and dorsal to a smaller membrane that completely en- 

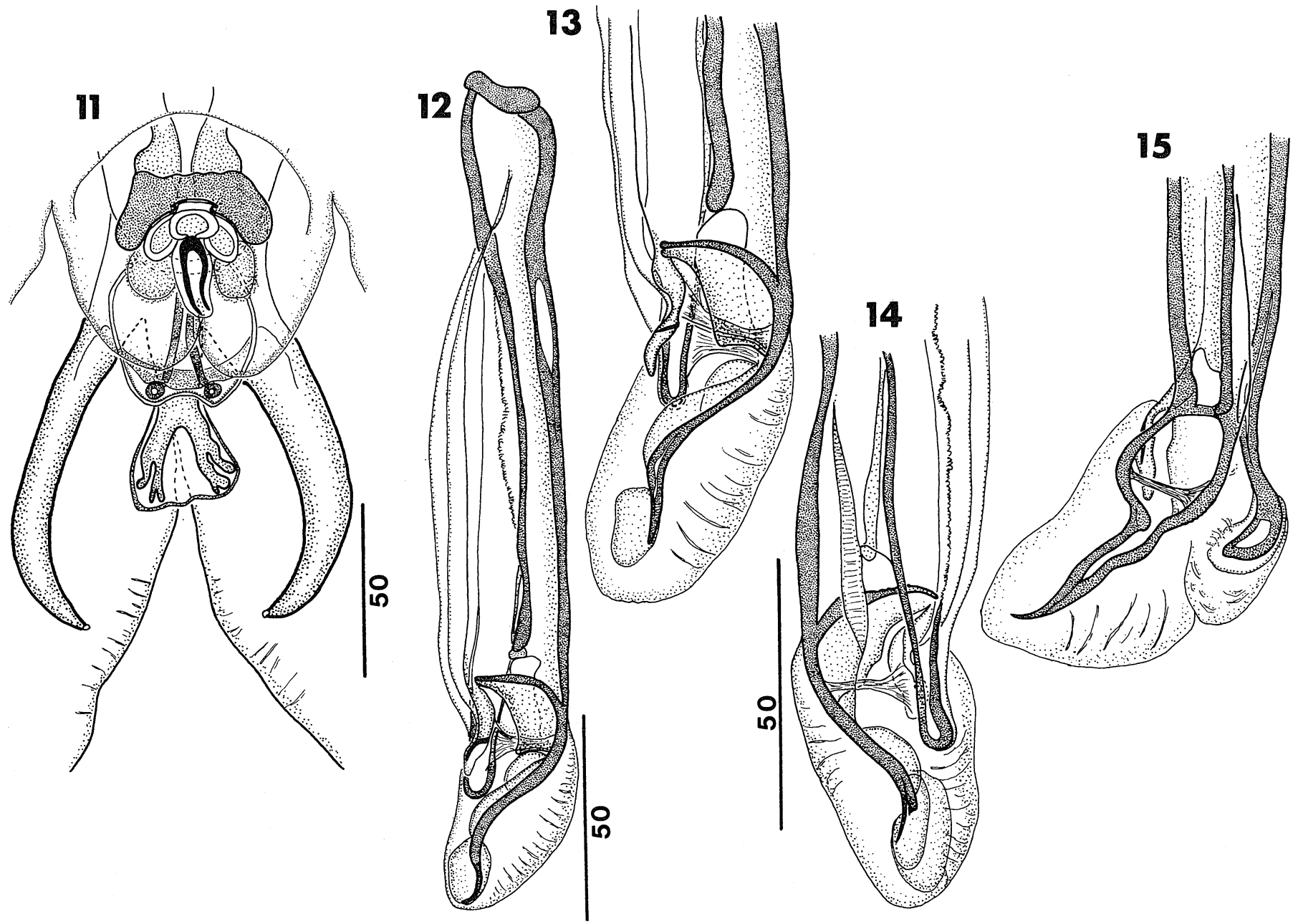

FIGURES 11-15. Mazamastrongylus dagestanica (Altaev, 1953) showing characters of the genital cone and spicules (scale bars in micrometers). 11. Genital cone in ventral view, showing " 0 " papillae, bilobed membrane, "7" papillae and accessory bursal membrane, and dorsal lobe. 12. Left spicule in ventral view. 13. Tip of left spicule, ventral view showing detail of structure distally. 14. Tip of left spicule in dorsal view. 15. Tip of left spicule in lateral view, from lateral to medial in orientation.

velops the " 0 " papillae. The accessory bursal membrane is ovoid and supported by parallel " 7 " papillae, which diverge distally (Figs. 11, 21). The dorsal ray is relatively short and bifurcates at approximately $60 \%$ from the anterior; distally there are 2 paired lateral processes. Rays $9 / 10$ are contained in a dorsal lobe, positioned ventrally to ray 8 (Fig. 11).

\section{Spicules}

The spicules are complex (Figs. 12-15, 17, 18). Single dorsal and ventral processes of unequal length and degree of cuticularization originate from the respective ala at $72-80 \%$ of the spicule length from the anterior. The ventral process is sinuous and obscure, with a weakly cuticularized joint in the distal third (Figs. 12, 13, 15, 17). The dorsal process is relatively long, slender, and spoon-shaped, extending approximately half the length of the main shaft from the trifurcation (Figs. 12-15, 18). The primary shaft of each spicule is split distally and surrounded by a granular membrane (Figs. 12-14); a strutlike bar connects the cuticularized alae in an expanded region near the tip and appears confluent with membranes associated with the dorsal and ventral processes (Figs. 13-15). The entire tip of the main shaft is encapsulated in a striated membrane (Figs. 12-15). A gubernaculum is absent.

\section{Females}

Specimens with a synlophe and esophageal structures identical to those found in males were considered to represent $M$. dagestanica. The vulva was located at $80-93 \%$ of body length from the anterior. Modification of the cuticle at the level of the vulva such as inflations were not observed. Vulval flaps were developed to varying degrees, or absent: among 40 specimens 13 had large prominent flaps (Figs. 22, 23), 14 had relatively small flaps (Figs. 24, 25) and 13 lacked a flap (Fig. 26). The lengths of the infundibula and sphincters did not differ substantially in the anterior and posterior (Figs. 24, 26; Table I). The length of the tail varied considerably (Table I); consistently several prominent annulations were present near the apex (Fig. 27). 


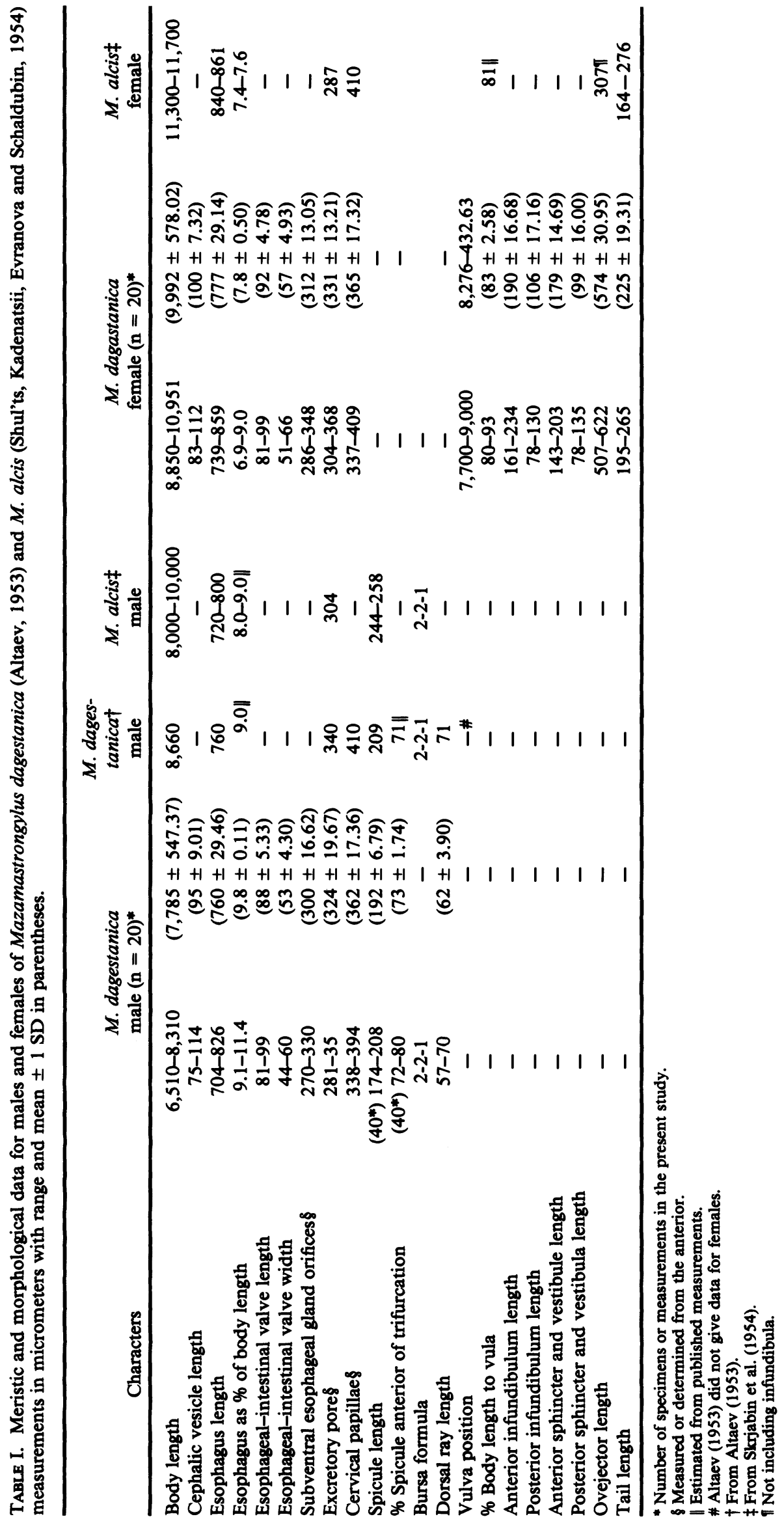




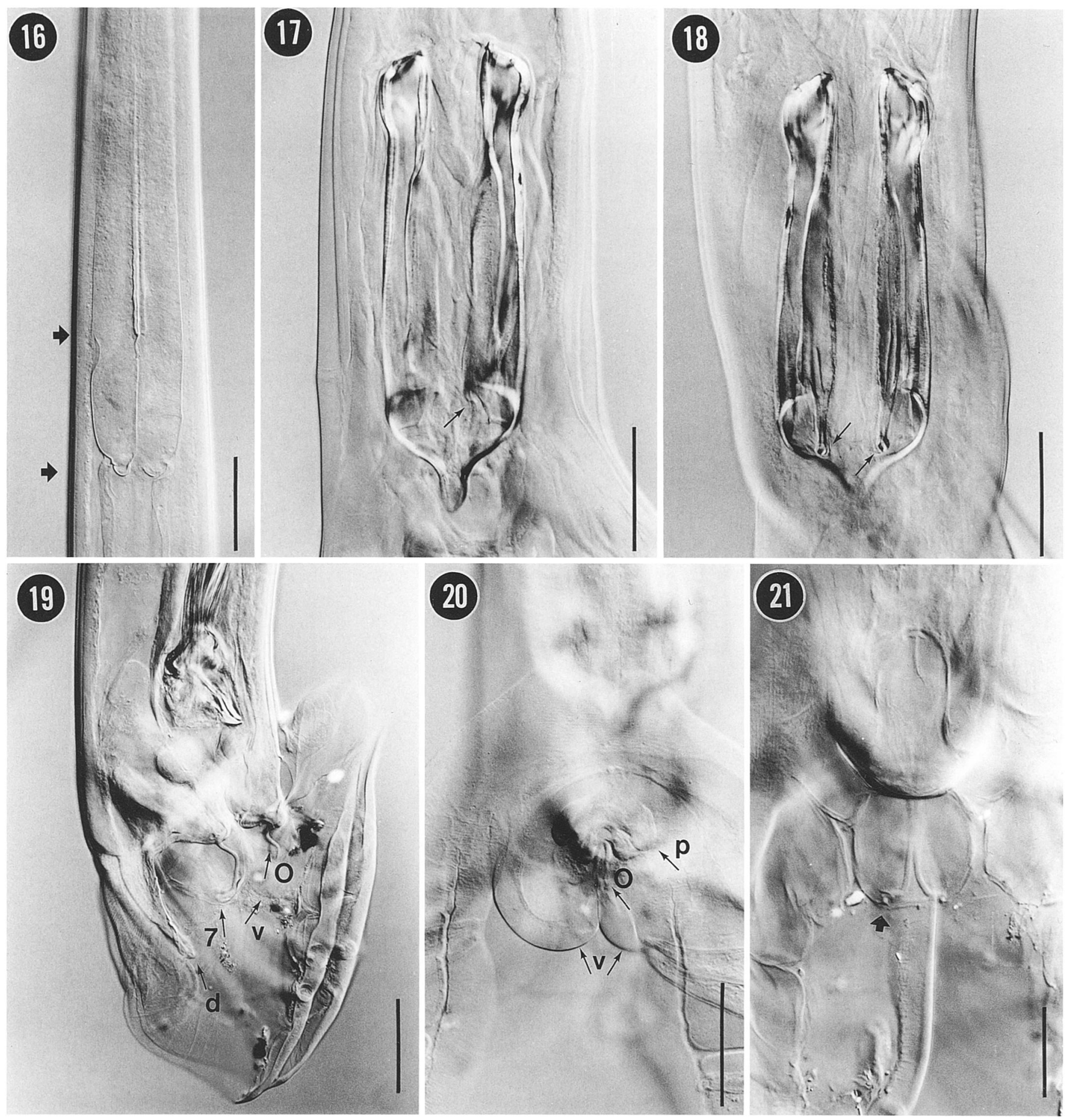

FIGURES 16-21. Mazamastrongylus dagestanica (Altaev, 1953) showing characters of male specimens as observed with interference contrast microscopy (scale bars $=50 \mu \mathrm{m}$; Fig. $21=30 \mu \mathrm{m}$ ). 16. Esophageal-intestinal valve (between arrows). 17. Spicules, ventral view showing poorly cuticularized and sinuous ventral process (arrow). 18. Spicules in dorsal view showing elongate and spoon-shaped dorsal process. 19. Bursa and genital cone in lateral view showing dorsal lobe (d), accessory bursal membrane and "7" papillae (7), bilobed ventral membrane (v), and "0" papillae (0). 20. Genital cone, ventral aspect showing lateral processes (p) extending from ventral cloacal plate, " 0 " papillae ( 0 ), and bilobed ventral membrane (v). 21. Genital cone, ventral view showing ovoid accessory bursal membrane and parallel "7" papillae that diverge distally.

\section{DISCUSSION}

Specimens of $M$. dagestanica as observed in the present study were generally consistent in structural and meristic characters with original descriptions and redescriptions including those of the synonym $S$. alcis (Table I; Altaev, 1953; Skrjabin et al., 1954). The configuration of the bursa, genital cone, and spicules is consistent with placement of this species in the genus $\mathrm{Ma}$ - 

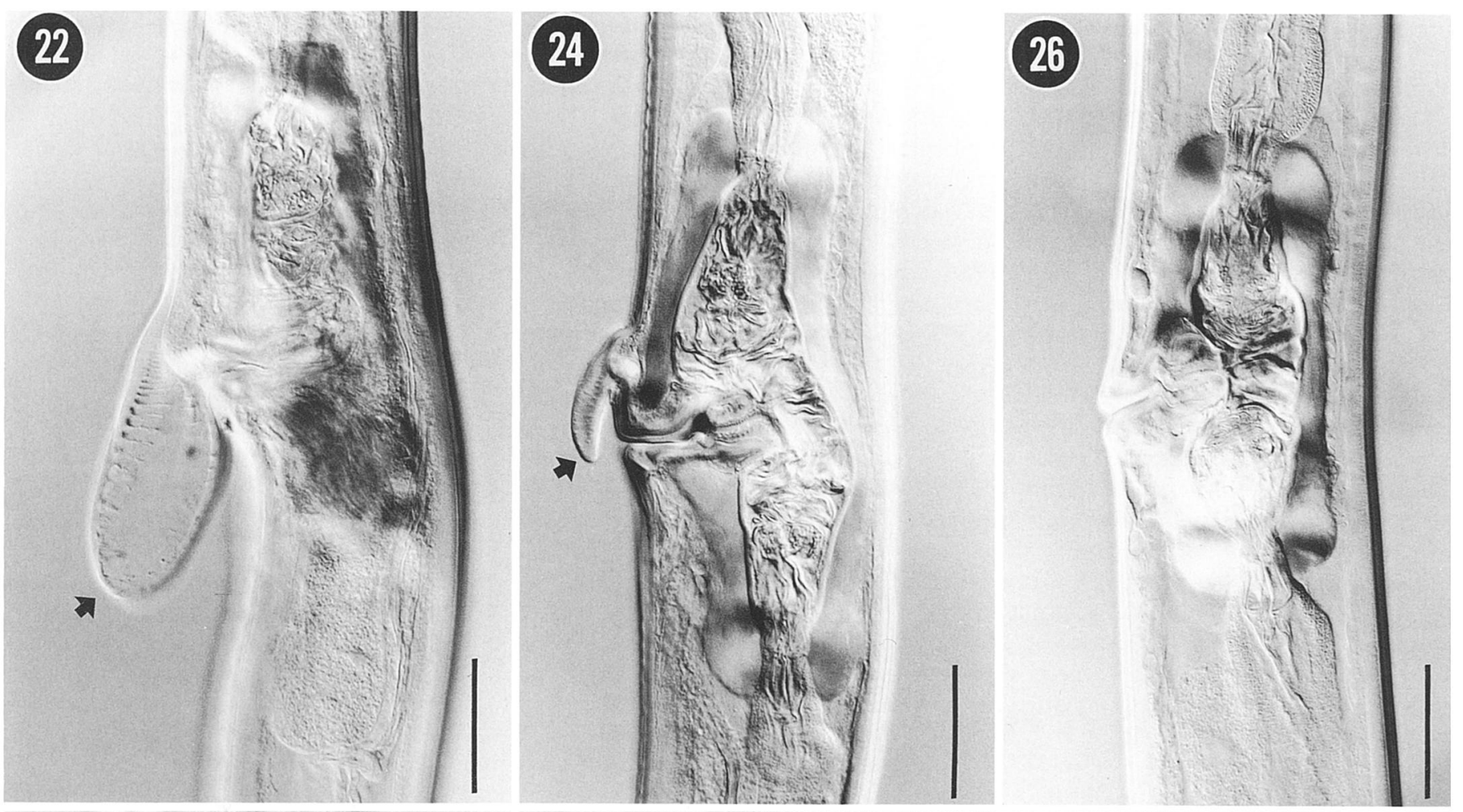

\section{3}
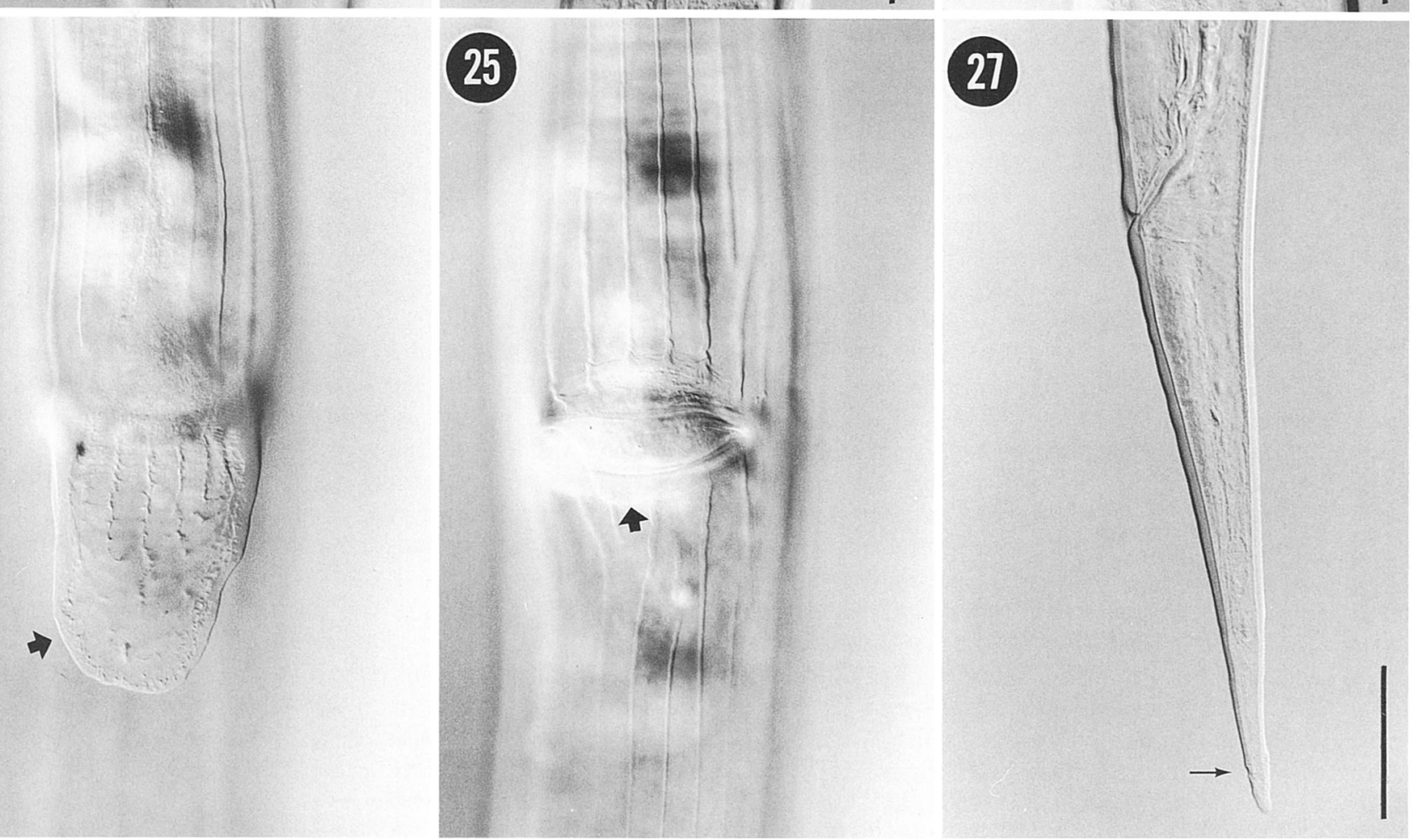

FIGUREs 22-27. Mazamastrongylus dagestanica (Altaev, 1953) showing characters of female specimens as observed with interference contrast microscopy (scales $=50 \mu \mathrm{m}$; same scale for 22-25). 22, 23. Specimen with large vulval flap in lateral and ventral views (arrow). 24, 25. Specimen with small vulval flap in lateral and ventral views (arrow); note structure of ovejector (excluding the infundibula) in Figure 24. 26. Specimens lacking vulval flap shown in lateral view. 27. Tail, showing typical annulations (arrow) near apex. 
zamastrongylus, based on a comparison with $M$. trinitatis (type) and other species of the genus (Jansen, 1986; Dróżdż, 1995; Hoberg, 1996).

The synlophe in males and females was found to be largely identical, consisting of 34-36 continuous and short discontinuous ridges at the level of the EI junction. The numbers of ridges were found to increase posteriad and usually attained a maximum of 38-44 in the anterior first quarter, decreasing to 3741 at the midbody. In contrast, Altaev (1953) reported 36-38 ridges "directly in front of the genital bursa" in the original description. Specimens of $M$. dagestanica (Figs. 6, 9) had a greater number of ridges in the midbody region (37-41) as compared to all species that have been examined, except $M$. peruvianus (see Jansen, 1986; Lichtenfels et al., 1993; Hoberg, 1996).

Species of Mazamastrongylus in which the synlophe has been examined are all characterized by a strongly tapering pattern in the lateral and ventral fields of the cervical zone (Lichtenfels et al., 1993; Hoberg, 1996). Specimens of $M$. dagestanica share with $M$. pursglovei, $M$. odocoilei, $M$. peruvianus, and $M$. trinitatis the prominent "hood" system adjacent to the excretory pore and absence of continuous subdorsal and subventral ridges. However, definable variation in the position and extent of the ventral ridge has not been demonstrated in these species. In $M$. peruvianus, the ventral ridge is interrupted only at the excretory pore (Hoberg, 1996). In contrast, in $M$. odocoilei and $M$. pursglovei the ventral ridge is discontinuous in the cervical zone (Lichtenfels et al., 1993) and is similar to the predominant pattern demonstrated for specimens of $M$. dagestanica.

Laterally, the structure of the synlophe typical of $M$. dagestanica (Figs. 2, 4) appears distinct from that described for $M$. odocoilei and $M$. pursglovei (same pattern for these species) and $M$. peruvianus. Consistently, 2 pairs of ridges converge and terminate along the lateralmost ridge anterior to the cervical papillae in specimens of $M$. dagestanica, a pattern not observed among other species. Thus, although the cervical synlophe is highly similar among those species of Mazamastrongylus that have been studied, species-level differences are definable. Thus, the largely identical synlophes of $M$. odocoilei and $M$. pursglovei could indicate a common ancestor for these species of Mazamastrongylus and a history of cospeciation with $O$. virginianus in North America (see also comments in Lichtenfels et al. [1993]).

In females of $M$. dagestanica, vulval flaps were present in $67 \%$ of specimens examined (Figs. 22-26), but cuticular crests or irregular inflations were not observed. Specimens of $S$. alcis were described with a prominent flap at the level of the vulva (Skrjabin et al., 1954). Among other species of Mazamastrongylus vulval flaps may be present or absent, typical of variation in this character among ostertagiines (Lancaster and Hong, 1990). Among species of Mazamastrongylus, asymmetric cuticular inflations in the vulval region have been observed in specimens of $M$. odocoilei, $M$. pursglovei, and $M$. trinitatis (see Hoberg et al., 1993b; Lichtenfels et al., 1993; Hoberg, 1996).

The structure of the bursa is of the 2-2-1 type (Altaev, 1953; Dróżdż, 1965) and the configuration of the ventral and lateral rays (rays 2-5) is consistent with placement in Mazamastrongylus (Jansen, 1986). The genital cone and particularly the configuration of the ventral cloacal plate, accessory bursal membrane, and " 7 " papillae (Figs. 11, 19-21) is typical of that described for $M$. trinitatis and other species of genus (Jansen, 1986; Lichtenfels et al., 1993; Hoberg, 1996). Lateral processes bordering the ventral cloacal plate (Stringfellow, 1971) appear typ- ical of several (Figs. 11, 20) species of Mazamastrongylus (see Lichtenfels et al., 1993). The "7" papillae are divergent distally and support an ovoid and weakly cuticularized accessory bursal membrane (Figs. 11, 21).

The delicate bilobed membrane on the ventral aspect of the genital cone in $M$. dagestanica has not been completely described (Figs. 11, 19, 20) and has been inconsistently depicted in published figures. For instance, the membrane was not described or shown by Altaev (1953) in the original description of $M$. dagestanica, nor was it shown in the figure of $S$. alcis provided by Dróżdż (1965). However, a well developed and symmetrical bilobed membrane is shown in figures of the genital cone of $S$. alcis reproduced by Skrjabin et al. (1954) and Andreeva (1958).

The distinctly bilobed structure represents a modification of the membranes that originate on the ventral aspect of the cloaca but which reside dorsal to the ventral raylets or " 0 " papillae (Figs. 11, 19, 20). The ventral membrane is balloonlike in appearance and easily collapsed. It extends from the posterolateral margins of the genital cone and ventral plate, residing ventral to the cloaca and dorsal to the " 0 " papillae. In contrast, the " 0 " papillae are contained in a distinct membrane that extends from the posterior margin of the ventral plate and terminates ventral to the ventral raylets. Thus, the bilobed ventral membrane is distinct from the simple and unpaired membrane that envelops the " 0 " papillae as depicted by Stringfellow $(1971,1972)$ and Gibbons and Khalil (1983). This is further indicated, as the bilobed membrane does not extend ventrally to the " 0 " papillae.

The ventral membrane was consistently present in all males examined in the current study. This attribute is also present in specimens of $M$. odocoilei (seen in lateral view in Fig. 20 of Lichtenfels et al. [1993], and in type specimens, USNPC no. 29427) and in $M$. pursglovei (based on examination of paratypes, USNPC no. 73914). In these species, the membrane is located in the same position but appears to be expanded to a lesser degree than in $M$. dagestanica (E. P. Hoberg, unpubl. obs.). This membrane was not depicted in the original description of either species from white-tailed deer (Dikmans, 1931; Davidson and Prestwood, 1979). Additionally, a characteristic bilobed membrane was depicted but not described by Dróżdż (1965) in specimens of Mazamastrongylus vietnamica (Dróżdż, 1965). Currently, this species is referred either to Spiculopteragia by Dróżdż (1995) or provisionally to Mazamastrongylus by Jansen (1986) and Hoberg (1996). Continued study will be necessary to reveal the potential utility of this membrane in elucidating some aspects of ostertagiine systematics.

Hoberg (1996) suggested that the structure of the spicules among species of Mazamastrongylus was a generic-level character. The spoon-shaped dorsal process and a sinuous and weakly cuticularized ventral process seen in $M$. dagestanica appear typical of this genus. However, the minuscule and obscure ventral process appears to be "reduced" with respect to this structure in other species. Altaev (1953) and Skrjabin et al. (1954) described a primary and dorsal process but apparently did not observe the ventral process. Additionally, the main, dorsal, and ventral processes lack trabeculate membranes, but the tip of each spicule is enveloped by a prominent striated membrane (see Hoberg, 1996). Although variation in length is apparent (Table I), structurally the spicules of $M$. dagestanica and $S$. alcis appear identical with respect to the primary and dorsal processes and terminal membranes (Altaev, 1953; Skrjabin et al., 1954). 
In agreement with Jansen (1986, 1989), Dróżdż (1995), and Hoberg (1996), characters of the bursa, genital cone, and spicules are consistent with placement of $M$. dagestanica in Mazamastrongylus. Thus, referral of this species to Spiculopteragia as advocated by Durette-Desset (1989) cannot be supported.

\section{ACKNOWLEDGMENTS}

Arthur Abrams of the BNPCU assisted in morphometric studies and in preparation of the synlophe figures. Patricia Pilitt of the BNPCU prepared transverse sections.

\section{LITERATURE CITED}

Altaev, A. K. 1953. Two new trichostrongylids from Dagestan sheep. Contributions to Helminthology published to commemorate the 75th birthday of K. I. Skrjabin. Izdatel'stvo Akademiia Nauk, SSSR, Moskva. [English translation by Israel Program for Scientific Translations, Jerusalem, 1966, p. 15-22.]

ANDREEVA, N. K. 1956. Revizia ostertagiei (trichostrongilid) zhvachnykh. Trudy Instituta Veterinarii 8: 473-487.

- 1958. Atlas of helminths (Strongylata) of domestic and wild ruminants of Kazakhstan. Institut Veterinarii Kazakhskogo Filiala VASKhNIL, Tashkent. [English translation by Agricultural Research Service, U.S. Department of Agriculture, and Amerind Publishing Company, New Delhi, 1978, 206 p.]

Cameron, T. W. M. 1935. Studies on the endoparasitic fauna of Trinidad mammals. 1. Some parasites of Trinidad deer. Canadian Journal of Research 13: 89-96.

Chabaud, A. G., F. Puylaert, O. Bain, A. J. Petter, and M.-C. DURETTE-DESSET. 1970. Remarques sur l'homologie entre les papilles cloacales des Rhabdites et les côtes dorsales des Strongylida. Comptes Rendus Hebdomadaire des Séances de l'Academie des Sciences, Paris 271: 1771-1774.

Davidson, W. R., AND A. K. Prestwood. 1979. Apteragia pursglovei sp. n. (Trichostrongyloidea: Trichostrongylidae) from the whitetailed deer, Odocoileus virginianus. Journal of Parasitology 65: 280 284.

Dikmans, G. 1931. Two new species of nematode worms of the genus Ostertagia from the Virginia deer, with a note on Ostertagia lyrata. Proceedings of the U.S. National Museum 79: 1-6.

DRóżż, J. 1965. Studies on the helminths and helminthiases in Cervidae I. Revision of the subfamily Ostertagiinae Sarwar, 1956 and an attempt to explain the phylogenesis of its representatives. Acta Parasitologica Polonica 13: 445-481.

- 1967. Studies on the helminths and helminthiases in Cervidae III. Historical formation of helminthofauna in Cervidae. Acta Parasitologica Polonica 14: 287-300.

- 1995. Polymorphism in the Ostertagiinae Lopez-Neyra, 1947 and comments on the systematics of these nematodes. Systematic Parasitology 32: 91-99.

Durette-DesSET, M. C. 1982. Sur les divisions génériques des Nématodes Ostertagiinae. Annales de Parasitologie Humaine et Comparée 57: 375-381.

- 1983. Keys to the genera of the superfamily Trichostrongyloidea. In $\mathrm{CIH}$ keys to the nematode parasites of vertebrates, Vol. 10, R. C. Anderson and A. G. Chabaud (eds.). Commonwealth Agricultural Bureaux, Farnham Royal, U.K., p. 1-86.

- 1985. Trichostrongyloid nematodes and their vertebrate hosts: Reconstruction of the phylogeny of a parasitic group. Advances in Parasitology 24: 239-306.

- 1989. Nomenclature proposée pour les espèces décrites dans la sous-famille des Ostertagiinae Lopez-Neyra, 1947. Annales de Parasitologie Humaine et Comparée 64: 356-373.

GibBONS, L. M., AND L. F. KhAlIL. 1982. A key for the identification of genera of the nematode family Trichostrongylidae Leiper, 1912. Journal of Helminthology 56: 185-233.

$\longrightarrow$, AND - 1983. Morphology of the genital cone in the nematode family Trichostrongylidae and its value as a taxonomic character. In Concepts in nematode systematics, Systematics Association Special Vol. 22, A. R. Stone, H. M. Platt, and L. F. Khalil (eds.). Academic Press, London, U.K., p. 261-271.
Govorka, IA., L. P. Maklakova, IA. Mrtukh, A. N. Pei'gunov, A. S. Rykovskit, M. K. Semenova, M. K. Sonin, B. ErkhardOVA-KOTRLA, AND V. IURASHEK. 1988. Gel'minty dikikh kopytnykh Vostochnoii Evropy. Akademiia Nauk SSSR Laboratoriia Gel'mintologii, Izdatel'stvo Nauka, Moskva, 207 p.

HinaIDY, H. K., AND H. Prosl. 1981. Proposals to the systematics of Ostertagia species: Tribe Spiculopteragia. Parasitology 82: 181183.

HOBERG, E. P. 1996. Emended description of Mazamastrongylus peruvianus (Nematoda: Trichostrongylidae), with comments on the relationships of the genera Mazamastrongylus and Spiculopteragia. Journal of Parasitology 82: 470-477.

$\longrightarrow$, AND J. R. LICHTENFELS. 1994. Phylogenetic systematic analysis of the Trichostrongylidae (Nematoda), with an initial assessment of coevolution and biogeography. Journal of Parasitology 80: 976996.

, - AND P. A. PIIITT. 1993a. Comparative morphology of Ostertagia mossi and Ostertagia dikmansi (Trichostrongylidae) from Odocoileus virginianus and comments on other Ostertagia spp. from the Cervidae. Systematic Parasitology 24: 111-127.

,--1 , AND $-1993 \mathrm{~b}$. Synlophe of Cooperia neitzi (Trichostrongylidae: Cooperiinae) with comments on vulval inflations and hypertrophy of cuticular ridges among the trichostrongylids. Journal of the Helminthological Society of Washington 60: 153161.

JANSEN, J. 1958. Lebmaagtrichostrongyliden bij Nederlandse herten. $\mathrm{Ph} . \mathrm{D}$ thesis. State University of Utrecht, Utrecht, Netherlands.

1986. Redescription of Mazamastrongylus trinitatis Cameron, 1935 and a discussion on the systematic position and species composition of the genus Mazamastrongylus Cameron, 1935 (Nematoda: Trichostrongyloidea). Systematic Parasitology 8: 279-283.

- 1989. A concise history of the Ostertagiinae Lopez-Neyra, 1947 (Nematoda: Trichostrongyloidea) and a discussion on its composition. Acta Leidensia 58: 158-159.

LANCASTER, M. B., AND C. HoNG. 1990. The identification of females within the subfamily Ostertagiinae Lopez-Neyra 1947 . Veterinary Parasitology 35: 21-27.

LiCHTENFels, J. R., AND E. P. Hoberg. 1993. The systematics of nematodes that cause ostertagiasis in domestic and wild ruminants in North America: An update and key to species. Second Ostertagia Workshop, University of Maryland. Veterinary Parasitology 46: 33-53.

$\longrightarrow$, AND P. A. PILITT. 1991. A redescription of Ostertagia bisonis (Nematoda: Trichostrongyloidea) and a key to species of Ostertagiinae with a tapering lateral synlophe from domestic ruminants in North America. Journal of the Helminthological Society of Washington 58: 231-244.

一, E. P. Hoberg, P. A. Pilitt, And A. M. G. Belem. 1993. A comparison of cuticular ridge patterns and other morphological characters of Mazamastrongylus odocoilei and Mazamastrongylus pursglovei (Nematoda: Trichostrongyloidea) from white-tailed deer Odocoileus virginianus. Systematic Parasitology 24: 1-15.

SARWAR, M. M. 1957. Observations on the morphology of Spiculopteragia asymetrica (Ware, 1925) and a discussion on its relationships. Zeitschrift für Parasitenkunde 18: $1-4$.

Skrjabin, K. I., N .P. Shikhobalova, R. S. Schulz, T. I. Popova, S. N. Boev, AND S. L. Delyamure. 1952. Key to the parasitic nematodes, Vol. 3. Strongylata. Izdatel'stvo Akademii Nauk SSSR, Moskva. [English translation, Israel Program for Scientific Translations, Jerusalem, 1961, 890 p.]

Skruabin, K. I., N. P. Shikhobalova, AND R. S. Shul'ts. 1954. Essentials of nematodology III. Trichostrongyloids of animals and man. Izdatel'stvo Akademii Nauk, SSSR, Moskva. [English translation by Israel Program for Scientific Translations, Jerusalem, 1960, 704 p.]

STRINGFELLOW, F. 1971. Functional morphology and histochemistry of structural proteins of the genital cone of Ostertagia ostertagi, with a comparison of the genital cones of other Ostertagia common in cattle in the United States. Journal of Parasitology 57: 823-831. . 1972. Comparative morphology of genital cones of Ostertagia from sheep in the United States. Journal of Parasitology 58: 265270. 